\title{
Semaphorin4A-Plexin D1 Axis Induces Th2 and Th17 While Represses Th1 Skewing in an Autocrine Manner
}

\author{
Tiago Carvalheiro ${ }^{1,2,+} \oplus$, Carlos Rafael-Vidal ${ }^{3,4,+}$, Beatriz Malvar-Fernandez ${ }^{1,2}$, Ana P. Lopes ${ }^{1,2}$, \\ Jose M. Pego-Reigosa ${ }^{3,4}$, Timothy R. D. J. Radstake ${ }^{1,2}$ and Samuel Garcia $1,2,3,4, *$ (D) \\ 1 Department of Rheumatology \& Clinical Immunology, University Medical Center Utrecht, \\ University of Utrecht, 3508 GA Utrecht, The Netherlands; t.ferreiracarvalheiro@umcutrecht.nl (T.C.); \\ beatrizmalvar@gmail.com (B.M.-F.); A.P.PinheiroLopes-3@umcutrecht.nl (A.P.L.); \\ tradstake73@gmail.com (T.R.D.J.R.) \\ 2 Center for Translational Immunology, University Medical Center Utrecht, University of Utrecht, \\ 3508 GA Utrecht, The Netherlands \\ 3 Rheumatology \& Immuno-mediated Diseases Research Group (IRIDIS), Galicia Sur Health Research \\ Institute (IIS Galicia Sur), SERGAS-UVIGO, 36312 Vigo, Spain; carlos.rafael@iisgaliciasur.es (C.R.-V.); \\ jose.maria.pego.reigosa@sergas.es (J.M.P.-R.) \\ 4 Rheumatology Department, University Hospital Complex of Vigo, 36312 Vigo, Spain \\ * Correspondence: samuel.garcia@iisgaliciasur.es; Tel.: +34-986-515-463 \\ + These authors equally contributed to this work.
}

Received: 31 August 2020; Accepted: 19 September 2020; Published: 22 September 2020

\begin{abstract}
Semaphorin (Sema) $4 \mathrm{~A}$ is a transmembrane glycoprotein that is elevated in several autoimmune diseases such as systemic sclerosis, rheumatoid arthritis and multiple sclerosis. Sema4A has a key role in the regulation of Thelper Th1 and Th2 differentiation and we recently demonstrated that $\mathrm{CD} 4^{+} \mathrm{T}$ cell activation induces the expression of Sema4A. However, the autocrine role of Sema4A on Th cell differentiation remains unknown. Naïve Th cells from healthy controls were cell sorted and differentiated into Th1, Th2 and Th17 in the presence or absence of a neutralizing antibody against the Sema4A receptor PlexinD1. Gene expression was determined by quantitative PCR and protein expression by ELISA and flow cytometry. We found that the expression of Sema4A is induced during Th1, Th2 and Th17 differentiation. PlexinD1 neutralization induced the differentiation of Th1 cells, while reduced the Th2 and Th17 skewing. These effects were associated with an upregulation of the transcription factor T-bet by Th1 cells, and to downregulation of GATA3 and ROR $\gamma \mathrm{t}$ in Th2 cells and Th17 cells, respectively. Finally, PlexinD1 neutralization regulates the systemic sclerosis patients serum-induced cytokine production by $\mathrm{CD}^{+} \mathrm{T}$ cells. Therefore, the autocrine Sema4A-PlexinD1 signaling acts as a negative regulator of Th1 skewing but is a key mediator on Th2 and Th17 differentiation, suggesting that dysregulation of this axis might be implicated in the pathogenesis of $\mathrm{CD}^{+} \mathrm{T}$ cell-mediated diseases.
\end{abstract}

Keywords: semaphorin4A; plexinD1; $\mathrm{CD}^{+} \mathrm{T}$ cell differentiation; $\mathrm{T}$ helper cells; systemic sclerosis

\section{Introduction}

$\mathrm{T}$ helper (Th) cells are essential regulators of the adaptive immune responses. There are three major subsets of Th cells, which can be identified based on their cytokine production and immune function. Th1 cells are characterized by the secretion of interferon- $\gamma$ (IFN- $\gamma$ ) and are involved in the host defense against intracellular pathogens; Th2 cells usually secret interleukin (IL)-4, IL-5 and IL-13 and are critical for mediating immune responses against extracellular parasites; finally Th17 cells mainly produce IL-17, IL-21 and IL-22, and are pivotal in the defense against extracellular bacteria and fungi [1-3]. Dysregulation of Th homeostasis has been implicated in several diseases. 
Hyperactivation of Th1 and Th17 cells confers susceptibility to autoimmune diseases and is associated with the pathology of multiple sclerosis (MS), inflammatory bowel disease, systemic sclerosis (SSc), psoriasis, rheumatoid arthritis (RA) and spondiloarthropaties [4-7]. On the other hand, Th2 cells are implicated in the pathogenesis of asthmatic and allergic diseases $[8,9]$.

Semaphorin (Sema) 4A is a transmembrane glycoprotein belonging to the semaphorin family, which is a large group of proteins initially described as axonal guidance molecules [10]. Sema4A is mainly produced by dendritic cells, monocytes and macrophages [11], although it can be also expressed by activated $\mathrm{CD} 4^{+} \mathrm{T}$ cells and germinal center B cells [12-14]. Sema4A binds to different receptors expressed on $\mathrm{CD}^{+}{ }^{+} \mathrm{T}$ cells, such as PlexinB1, PlexinB2, PlexinD1, Neuropilin-1 (NRP-1), Immunoglobulin-like transcript 4 (ILT) 4 and Tim-2, although the last has been reported in mice and has no human orthologous [12-18]. Several studies have shown that Sema4A expression is elevated in diseases in which Th cells play an essential role, including asthma, RA, MS and SSc [11-13,19]. Furthermore, functional studies have demonstrated that Sema4A is a key molecule in the regulation of naïve $\mathrm{CD} 4^{+} \mathrm{T}$ cell differentiation, although different effects in mouse and human $\mathrm{CD} 4^{+} \mathrm{T}$ cells have been reported. In mice, Sema $4 \mathrm{~A}$ is involved in T cell priming and Th1 skewing, both processes mediated by Tim-2 $[14,20]$. Besides that, Sema4A deficiency induces Th2 skewing and enhances the severity of allergic responses [21-23]. Finally, Sema4A induced the expression of IL-17 by CD4 ${ }^{+} \mathrm{T}$ cells from autoimmune encephalomyelitis mice $[11,24]$. In human $\mathrm{CD} 4^{+} \mathrm{T}$ cells, exogenous Sema4A induces ILT- 4 mediated Th2 differentiation and, on the contrary to mice studies, inhibits Th1 skewing. Moreover, we also found that Sema4A secreted by activated $\mathrm{CD}^{+} \mathrm{T}$ cells of SSc patients is able to induce the expression of Th17 cytokines in a PlexinB2, PlexinD1 and NRP-1 dependent manner [12,13].

Altogether, these data demonstrate that exogenous Sema4A is involved in human naïve Th cell differentiation. However, whether autocrine Sema4A is involved on this process and the functional consequences of its inhibition are still unknown.

\section{Results}

\subsection{Sema4A Is Induced During $C D 4^{+} T$ Cell Differentiation}

Although previous reports have shown that Sema4A is not expressed in naïve $\mathrm{CD} 4^{+} \mathrm{T}$ and only induced after $\mathrm{CD} 4^{+} \mathrm{T}$ cells activation [12,13], its expression during Th cell differentiation is still unknown. Indeed, unstimulated naïve $\mathrm{CD} 4^{+} \mathrm{T}$ cells did not express SEMA4A. However, upon Th1, Th2 and Th17 differentiation SEMA4A expression is upregulated at day 3, although differences were only significant in the Th2 subset. Despite the lower gene expression levels compared to day 3, at day 7 we still observed an upregulation of SEMA4A (Figure 1A). In addition, we also determined the effect of Th differentiation on the secretion of Sema4A. At day 3, the Sema4A levels were already elevated in the three Th cell subsets compared to the non-stimulated naïve $\mathrm{CD} 4^{+} \mathrm{T}$ cells, even though it was only significant in the Th17 subset. At day 7, the secretion of Sema4A was significantly higher in the three differentiated Th subsets compared to the non-differentiated naïve T cells (Figure 1B).
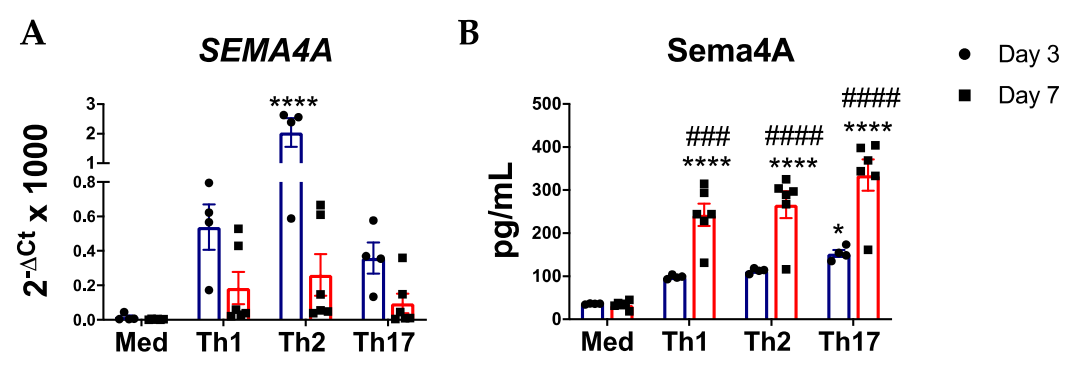

Figure 1. Sema4A is induced during $T$ helper cell differentiation. Sema4A mRNA (A) and protein (B) levels in unstimulated naïve CD4 ${ }^{+} \mathrm{T}$ cells or in Th1, Th2 or Th17 differentiated cells for 3 days $(n=4)$ and 7 days $(n=6)$. Means and SEM are shown. ${ }^{*} p<0.05$ and ${ }^{* * * *} p<0.0001$ compared to the medium at day 3. \#\#\# $p<0.001$ and \#\#\#\# $p<0.0001$ compared to the medium at day 7. 


\subsection{Autocrine Sema4A-plexinD1 Signaling Induces Th2 and Th17 Differentiation and Suppresses Th1 Skewing}

We have previously shown that neutralization of autocrine/paracrine Sema4A signaling reduced the expression of Th17 cytokines by the total $\mathrm{CD}^{+} \mathrm{T}$ cells [13], thus we next analyzed the effect of the inhibition of this signaling during Th helper cell differentiation. For this purpose we used an anti-PlexinD1 neutralizing antibody, as PlexinD1 is the most expressed Sema4A receptor in naïve $\mathrm{CD}^{+} \mathrm{T}$ cells [13]. Compared to the respective isotype control, the neutralization of PlexinD1 induced the expression of IFNG in Th1-diferentiated cells, while it reduced the expression of Th2 cytokines (IL4 and IL5), and Th17 cytokines (IL17 and IL22) cytokines by Th2 and Th17 differentiated cells, respectively. TNF expression was upregulated in the three cell subsets but the expression was not modulated by the PlexinD1 neutralization (Figure 2). Consistently, we also found these effects earlier in the differentiation process, as at day 3 PlexinD1 blocking upregulated IFNG levels and reduced IL4 and IL17 expression in the respective Th subsets, Th1, Th2 and Th17 (Figure S1).
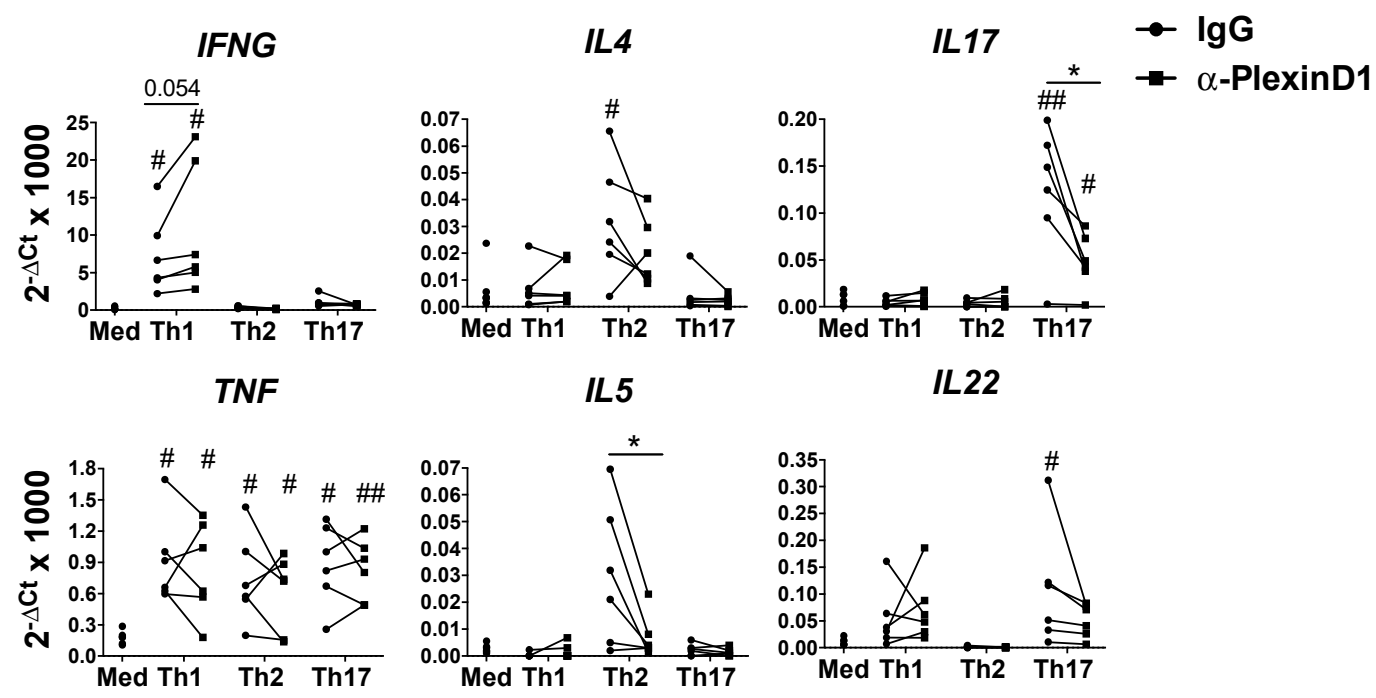

Figure 2. Sema4A-PlexinD1 axis inhibits Th1 and promotes Th2 and Th17 differentiation. Cytokines mRNA expression in naïve CD4 ${ }^{+} \mathrm{T}$ cells differentiated either in medium (Med), Th1, Th2 or Th17 differentiation cocktails in the presence of an anti-PlexinD1 antibody or its respective isotype control for 7 days $(n=6)$. Data is presented as connected dots. ${ }^{*} p<0.05$. $\# p<0.05$ and $\# \# p<0.01$ compared to the medium.

We next confirmed these results at the protein level; on Th1 cells, PlexinD1 neutralization significantly increased the secretion of IFN $\gamma$ and showed a trend towards a higher production of this cytokine after restimulation with PMA/ionomycin. On the other hand, neutralization of the Sema4A-PlexinD1 signaling significantly reduced the secretion and the production of IL-4 and IL-17 by Th2 and Th17 cells, respectively (Figure 3A,B and Supplementary Figure S2). We also observed a reduction on IL-22 production by Th17 cells, but differences were not significant (Figure 3B).

To rule out the possibility of unspecific effects due to cell viability and/or proliferation, we analyzed the viability of a naïve $\mathrm{CD} 4^{+} \mathrm{T}$ cell and proliferation during differentiation. At day 3, non-differentiated naïve $\mathrm{T}$ cells did not proliferate, but in the Th1, Th2 and Th17 subsets, the proliferation rate was nearly $100 \%$, independent of PlexinD1 neutralization (Figure S3A). Overall, cell viability was similar through all the culture conditions either at day 3 and day 7, without effect of the PlexinD1 neutralization. Nevertheless, the overall cell viability at day 7 was slightly lower compared with day 3 (Figure S3B). 
A
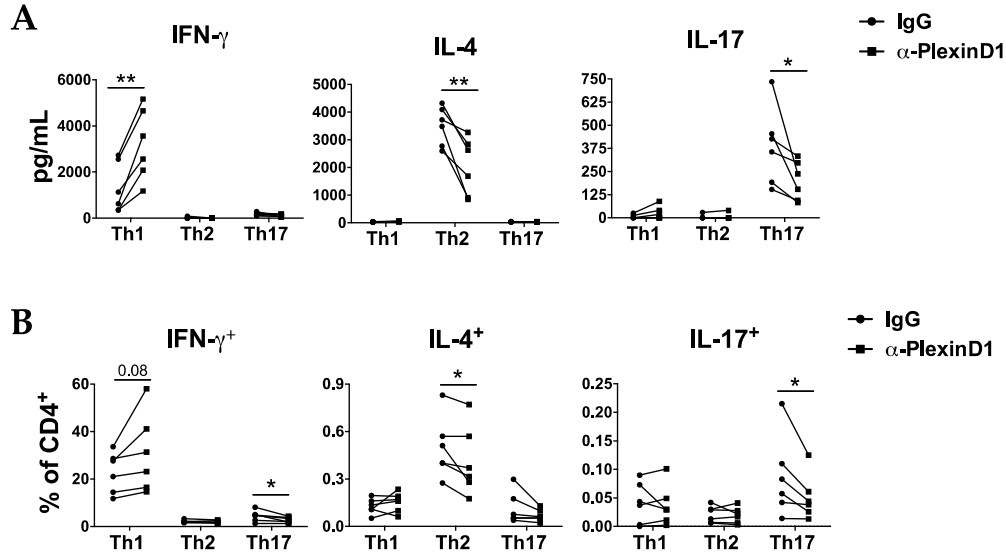

$\mathrm{TNF}^{+}$

$\mathrm{IL}-13^{+}$

IL-22+

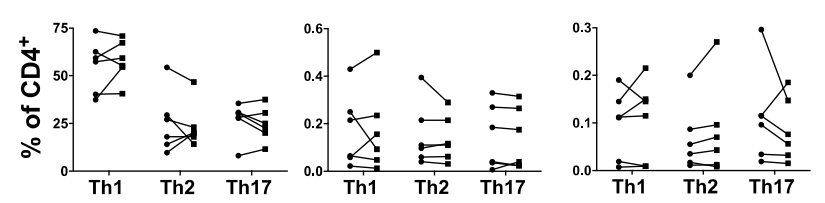

Figure 3. Sema4A-PlexinD1 axis inhibits Th1 and promotes Th2 and Th17 differentiation. Cytokine secretion (A) and intracellular cytokine production (B) in naïve CD4 ${ }^{+} \mathrm{T}$ cells differentiated with Th1, Th2 or Th17 differentiation cocktails in the presence of an anti-PlexinD1 antibody or its respective isotype control for 7 days $(n=6)$. Data is presented as connected dots. ${ }^{*} p<0.05$ and ${ }^{* *} p<0.01$.

\subsection{PlexinD1 Neutralization Regulates TBX21, GATA3 and RORC Expression}

We next analyzed whether PlexinD1 neutralization also modulates the expression of T-bet, GATA3 and ROR $\gamma \mathrm{t}$, the master transcription factors involved in Th cell differentiation [3]. The expression levels of TBX21, the gene encoding T-bet, was increased on Th1-differentiated cells at day 3 and 7 of differentiation in the presence of the anti-PlexinD1 antibody. On the contrary, GATA3 expression was reduced on Th2-differentiated cells at both day 3 and 7, although differences were not significant. Similarly, PlexinD1 neutralization significantly reduced the expression of RORC, the gene that encodes ROR $\gamma \mathrm{t}$, in Th17 cells at day 3 and 7 (Figure 4A,B). Therefore, our data suggest that Sema4A-PlexinD1 axis impacts the expression of master transcription factors involved in the Th cell differentiation processes.

A

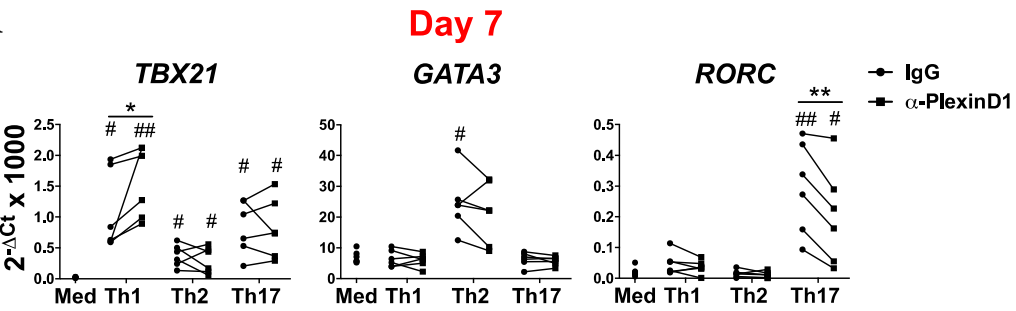

B

\section{Day 3}

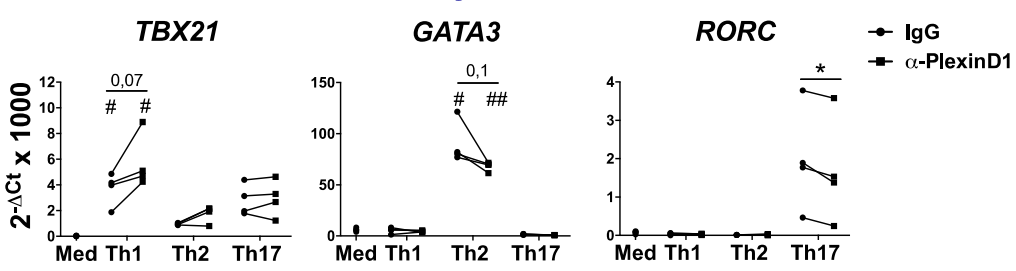

Figure 4. Sema4A-PlexinD1 axis regulates the expression of transcription factors involved in T helper cell differentiation. (A,B) TBX21, GATA3 and RORC expression in naïve CD4 ${ }^{+} \mathrm{T}$ cells differentiated either 
in medium or Th1, Th2 or Th17 differentiation cocktails in the presence of an anti-PlexinD1 antibody or its respective isotype control for 7 days $(\mathbf{A}, n=6)$ and 3 days $(\mathbf{B}, n=4)$. Data is presented as connected dots. ${ }^{*} p<0.05$ and ${ }^{* *} p<0.01$. \# $p<0.05$ and \#\# $p<0.01$ compared to the medium.

\subsection{Sema4A-PlexinD1 Blockade Reduces PlexinB2 Expression during Th17 Cell Differentiation}

As Sema4A has multiple receptors [10], we also determined whether blockade of the Sema4A-PlexinD1 axis modulates the expression of Sem4A receptors. The neutralization of PlexinD1 did not affect the mRNA expression of PlexinD1, PlexinB1, NRP-1 or ILT-4 in any of the subsets analyzed at day 7 (Figure 5A). However, PlexinD1 blockage led to a significant reduction in PLEXINB2 expression in Th17-diferentiated cells at both day 3 and 7 (Figure 5B,C) and to a lower percentage of PlexinB2 positive cells at day 3 of Th17 differentiation (Figure 5D and Figure S4).

\section{A}

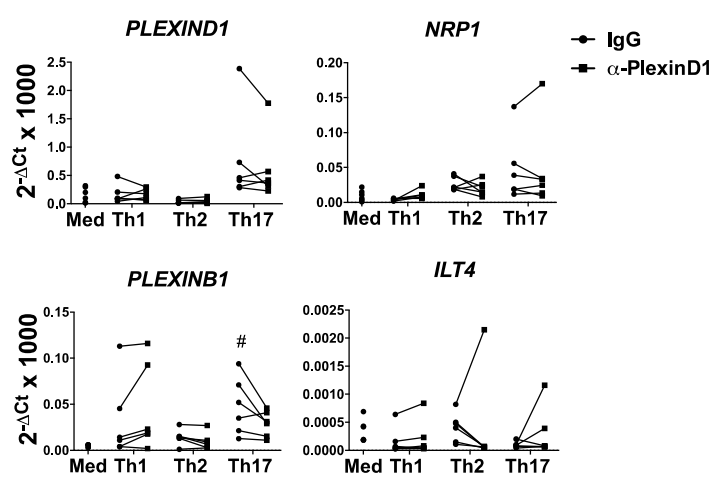

B

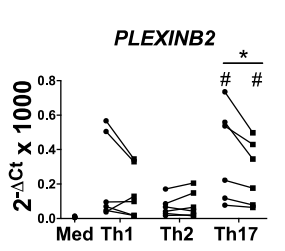

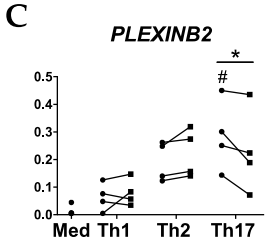

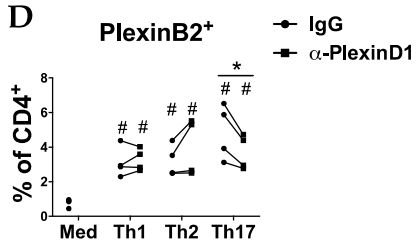

Figure 5. Sema4A-PlexinD1 axis induces the expression of PlexinB2 in Th17 cells. (A) mRNA expression of Sema4A receptors in naïve $\mathrm{CD} 4^{+} \mathrm{T}$ cells differentiated in medium or Th1, Th2 or Th17 differentiation cocktails in the presence of an anti-PlexinD1 antibody or its respective isotype control for 7 days $(n=6)$. (B-D) PlexinB2 mRNA $(\mathbf{B}, \mathbf{C})$ and protein $(\mathbf{D})$ expression in naive $\mathrm{CD} 4^{+} \mathrm{T}$ cells differentiated in medium or Th1, Th2 or Th17 differentiation cocktails in the presence of an anti-PlexinD1 antibody or its respective isotype control for 7 days $(\mathbf{B}, n=6)$ and 3 days $(\mathbf{C}, \mathbf{D}, n=4)$. Data are presented as connected dots. ${ }^{*} p<0.05$. $\# p<0.05$ compared to the medium.

\subsection{PlexinD1 Neutralization Regulates $C D 4^{+} T$ Cells Cytokine Production Induced by Systemic Sclerosis} Patient Serum

Previously we have shown that Sema4A is elevated in the serum of SSc patients and it induces the production of Th17 cytokines [13]. In addition, both IL-17 and IL-4 cytokines are elevated in SSc patients and have been shown to play an important role in SSc pathogenesis [25-29]. Thus, in order to confirm the functional role of the Sema4A-PlexinD1 axis on a $\mathrm{CD}^{+} \mathrm{T}$ cell-mediated disease, we investigated the role of PlexinD1 neutralization on the $\mathrm{CD}^{+} \mathrm{T}$ cells cytokine production induced by the serum of SSc patients. In CD4 ${ }^{+} \mathrm{T}$ cells activated in the presence of SSc-serum, the neutralization of PlexinD1 significantly induced the secretion of IFN- $\gamma$, while the secretion of IL-17 was significantly reduced (Figure 6). The secretion of IL-4 despite the low production and undetectable in some donors, shows a trend towards a reduction after the neutralization of PlexinD1 (Figure 6). Altogether, these data 
suggest that Sema4A-PlexinD1 signaling is involved in the elevated levels of IL-17 and IL-4 observed in these patients.
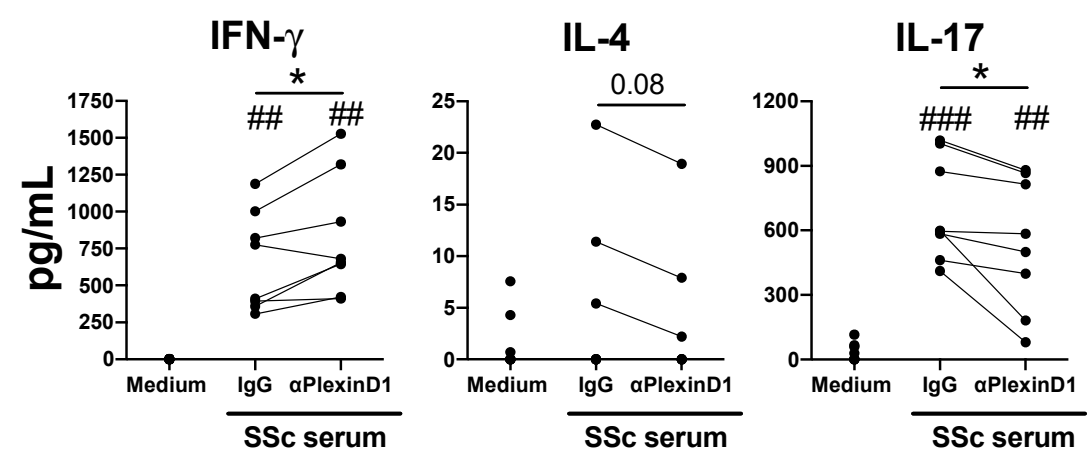

Figure 6. Sema4A-PlexinD1 axis regulates $\mathrm{CD}^{+} \mathrm{T}$ cytokine production induced by systemic sclerosis patient serum. IFN- $\gamma$, IL-4 and IL-17 secretion by activated CD4 ${ }^{+} \mathrm{T}$ cells, pretreated for $1 \mathrm{~h}$ with an anti-PlexinD1 antibody or its respective isotype control (IgG) and incubated with the serum of SSc patients $(20 \% v / v)$ for 5 days $(n=8)$. Data are presented as connected dots. ${ }^{*} p<0.05$. \#\# $p<0.01$ and \#\# $p<0.001$ compared to medium.

\section{Discussion}

Here, we demonstrated the role of autocrine Sema4A-PlexinD1 axis on $\mathrm{CD}^{+} \mathrm{T}$ cell differentiation and its contribution to T cell-mediated diseases. Previous reports have shown that Sema4A is expressed by activated $\mathrm{CD}^{+} \mathrm{T}$ cells and memory Th2 cells $[12,13]$. Here we first show that the expression of Sema4A was induced during the $\mathrm{CD}^{+} \mathrm{T}$ differentiation and, together with the fact that Sema4A was involved in $\mathrm{T}$ cell activation and differentiation, suggest that autocrine Sema4A may be involved in these processes.

Secondly, we demonstrated that the autocrine Sema4A-PlexinD1 axis was a negative regulator of human Th1 differentiation and played a crucial role in Th2 skewing. These findings are in accordance with the work of $\mathrm{Lu} \mathrm{N}$ et al. [12], in which exogenous Sema4A administration repressed Th1 differentiation and induced Th2 skewing. In addition, we unprecedently showed that Sema4A-PlexinD1 axis is also involved on Th17 differentiation, which is in line with previous works, which demonstrate that Sema4A induces IL-17 production in both mouse and human CD4 ${ }^{+} \mathrm{T}$ cells $[11,13,24]$. Importantly, the effect of the Sema4A-PlexinD1 axis on Thelper cell differentiation is supported by the regulation of the master transcription factors T-bet, GATA3 and RORC. Similarly to our previous work [13], but on the contrary to the work of $\mathrm{Lu} \mathrm{N}$ et al. [12], the autocrine Sema4A-PlexinD1 signaling did not affect the $\mathrm{CD} 4^{+} \mathrm{T}$ cell proliferation. These differences may be attributed to the stimulation with exogenous Sema4A, the use of $\mathrm{CD}^{+} \mathrm{T}$ cells from buffy coats and the different manner of $\mathrm{CD} 4^{+} \mathrm{T}$ cell activation, as these authors used an anti-CD3 antibody at a suboptimal concentration and did not activated the CD28 signaling pathway. Altogether, these data suggest that the Sema4A-PlexinD1 axis might be implicated in the maintenance of the homeostatic levels of Th1, Th2 and Th17 cells and therefore in the proper host defense against intracellular and extracellular pathogens [1,2]. This role of Sema4A-PlexinD1 was observed in combination with key cytokines involved on Th differentiation, such as IL12 (Th1), IL-4 (Th2) and IL-23 (Th17) $[4,5,9]$. However, whether Sema4A is capable of modulating Th differentiation in the absence of these cytokines or is a costimulatory pathway implicated in Th skewing needs to be further elucidated.

Sema4A binds to different receptors in a cell type and context dependent manner [10,30]. Here we found that PlexinD1 is involved in the differentiation of three $\mathrm{CD} 4^{+} \mathrm{T}$ subsets. To our knowledge PlexinD1 is the only Sema4A receptor involved in the inhibition of Th1 differentiation, while in the Th2 skewing both PlexinD1 and ILT-4 are implicated [12]. The neutralization of Sema4A-PlexinD1 axis downregulated the expression of PlexinB2 in Th17 cells, and as PlexinB2 is involved in the secretion of Th17 cytokines by activated CD4 ${ }^{+}$T cells [13], the Sema4A-PlexinB2 axis seems also to be implicated 
in the Th17 skewing. Hence, Sema4A plays a central role in $\mathrm{CD}^{+} \mathrm{T}$ cell differentiation through the involvement of different receptors. Nevertheless, the role of other Sema4A receptors involved in $\mathrm{T}$ cell function, such as NRP-1, PlexinB1 or PlexinB2 needs to be elucidated.

Lastly, we translated our findings to a $\mathrm{CD} 4^{+} \mathrm{T}$ cell-mediated disease and we demonstrated that the neutralization of PlexinD1 suppressed the CD4 ${ }^{+} \mathrm{T}$ cell secretion of IL-17 and IL-4 induced by the serum of SSc patients. Although PlexinD1 can bind to other semaphorin family members, mainly Sema3E [10,31], but also Sema3C, Sema3D and Sema3G [32-34], Sema4A is the only known PlexinD1 ligand able to induce $T$ cell activation. This fact, together with the elevated Sema4A expression observed in SSc patients [13], suggest that the Sema4A-PlexinD1 axis is responsible, at least in part, for the elevated IL-4 and IL-17 levels observed in these patients. As Sema4A expression is also elevated in other $\mathrm{CD}^{+}{ }^{+} \mathrm{T}$ cell-mediated diseases including, asthma, RA and MS [11,12,19,24], it is tempting to speculate that Sema4A-PlexinD1 signaling is involved in the dysregulation of Th cell homeostasis observed in these diseases and targeting this axis might be a beneficial therapeutic approach. As binding of PlexinD1 to its different ligands is not only involved in T cell differentiation, but also plays a key role in vascular, cardiac, skeletal and neuronal development and homeostasis [35-40], we consider that neutralizing Sema4A might be a better therapeutic option than blocking PlexinD1. A limitation of our study is that we could not test this possibility, due to the lack of commercially available anti-Sema4A neutralizing antibodies. Therefore, further studies using other methodologies such as gene silencing or deletion are needed to elucidate the pathological role of Sema4A on $\mathrm{CD} 4^{+} \mathrm{T}$ cell-mediated diseases.

\section{Materials and Methods}

\subsection{Nä̈ve $C D 4^{+} T$ Cell Isolation}

Peripheral blood mononuclear cells (PBMCs) from healthy controls were isolated by the Ficoll gradient (GE Healthcare, Zwijndrecht, The Netherlands). Cells were further isolated using the CD4+ T Cell Isolation Kit on an autoMACS Pro Separator, according to the manufacturer's instructions (Miltenyi Biotec, Leiden, The Netherlands). To isolate the naïve subpopulation, total $\mathrm{CD} 4^{+} \mathrm{T}$ cells were stained with anti-CD4 APC-eF780 (eBioscience, Nieuwegein, The Netherlands), anti-CD27 BV510 (Biolegend, Amsterdam, The Netherlands), anti-CD25 PE, anti-CD127 Alexa Fluor-647 and anti-CD45RO PE/Cy7 (BD Biosciences, Vianen, The Netherlands) antibodies and purified on a BD FACSAria ${ }^{\mathrm{TM}}$ III cell sorter (BD Biosciences, Vianen, The Netherlands). Naïve CD4 + CD25-CD27 ${ }^{+} \mathrm{CD} 45 \mathrm{RO}^{-} \mathrm{T}$ cells were defined according to the gating strategy shown in Figure S5. Purity was consistently $>99 \%$.

\subsection{Naïve $C D 4^{+} T$ Cell Differentiation}

Naïve $\mathrm{CD} 4^{+} \mathrm{T}$ cells were preincubated for $1 \mathrm{~h}$ with the neutralizing antibody anti-PlexinD1 or its respective isotype control, goat IgG (both $2.5 \mu \mathrm{g} / \mathrm{mL}$, R\&D systems, Abingdon, United Kingdom) in RPMI-GlutaMAX (Thermo Fisher Scientific, Nieuwegein, The Netherlands) supplemented with 10\% fetal bovine serum (FBS, Biowest, Amsterdam, The Netherlands), 10.000 I.E. penicillin-streptomycin (Thermo Fisher Scientific, Nieuwegein, The Netherlands) and 1:500 Primocin (Invivogen, Toulouse France). Next, cells were activated with Dynabeads Human T-Activator CD3/CD28 (Thermo Fisher Scientific, Nieuwegein, The Netherlands) at a bead-to-cell ratio of 1:5 and differentiated either to Th1, Th2 or Th17 for 7 days with the specific T helper cell differentiation cocktails (Table S1). At day 3 , half of the medium was replaced with fresh medium containing the differentiation cocktails and the anti-PlexinD1 antibody or the isotype control. For the intracellular cytokine staining, $1 \mu \mathrm{g} / \mathrm{mL}$ of phorbol 12-myristate 13-acetate (PMA), $50 \mathrm{ng} / \mathrm{mL}$ of ionomycin (both from Sigma Aldrich, Zwijndrecht, The Netherlands) and $1 \mu \mathrm{g} / \mathrm{mL}$ of GolgiStop (BD Biosciences, Vianen, The Netherlands) were added for the final $4 \mathrm{~h}$ of stimulation. 


\section{3. $C D 4^{+} T$ Cell Stimulation}

Total $\mathrm{CD} 4^{+} \mathrm{T}$ cells were pretreated for $1 \mathrm{~h}$ with the anti-PlexinD1 antibody or its respective isotype control IgG (both $2.5 \mu \mathrm{g} / \mathrm{mL}$ ) and then activated with Dynabeads Human T-Activator CD3/CD28 (Thermo Fisher Scientific, Nieuwegein, The Netherlands) at a bead-to-cell ratio of 1:5 and incubated with the serum of SSc patients $(20 \% v / v)$, for 5 days. All included patients fulfilled the ACR/EULAR 2013 classification criteria for SSc [41]. All patients provided informed written consent approved by the local institutional medical ethics review boards prior to inclusion in this study (NL47151.041.13, on 29 November 2013). Samples and clinical information were treated anonymously immediately after collection. Demographics and clinical characteristics of the included patients are detailed in Table S2.

\subsection{Flow Cytometry}

$\mathrm{CD}^{+}{ }^{+} \mathrm{T}$ cells were stained with Fixable Viability Dye (eBioscience, Nieuwegein, The Netherlands), and antibodies for PlexinB2 APC and its respective isotype control (both from R\&D systems, Abingdon, United Kingdom). Alternatively, cells were fixed and permeabilized using the Foxp3/Transcription Factor Staining Buffer Set (eBioscience, Nieuwegein, The Netherlands), and stained for IL-17A FITC, IL-22 APC, IFN $\gamma$ PerCP-Cy5.5 (all from eBioscience, Nieuwegein, The Netherlands), IL-4 BV711, IL-13 PE and TNF BV421 (all from BD Biosciences, Vianen, The Netherlands). For proliferation analysis, $\mathrm{CD}^{+} \mathrm{T}$ cells were labeled with CellTrace Violet $(1.5 \mu \mathrm{M}$, Thermo Fisher Scientific, Nieuwegein, The Netherlands) prior to culture. Samples were acquired on a BD LSR Fortessa (BD Biosciences), or on a BD FACSCanto (BD Biosciences, Vianen, The Netherlands) using the BD FACSDiva software (BD Biosciences, Vianen, The Netherlands). FlowJo software (BD Biosciences, Vianen, The Netherlands) was used for data analyses. All flow cytometry data is presented as the percentage of positive cells.

\subsection{Cytokine Measurement}

Sema4A (Biomatik LLC, Wilmington, DE, USA), IL-17A, IFN- $\gamma$ (eBioscience, Nieuwegein, The Netherlands) and IL-4 (R\&D systems, Abingdon, United Kingdom) were measured by ELISA in cell-free supernatants, according to the manufacturer's instructions.

\subsection{RT-PCR and Quantitative $q P C R$}

RNA was isolated using the RNeasy micro Kit and RNase-Free DNase Set (Qiagen, Venlo, The Netherlands). Total RNA was reverse-transcribed using an iScript cDNA Synthesis kit (Biorad, Veenendaal, The Netherlands). qPCR reactions were performed using SYBR green (Applied Biosystem, Nieuwerkerk aan Den Ijssel, The Netherlands) with a StepOne Plus Real-Time PCR system (Applied Biosystems, Nieuwerkerk aan Den Ijssel, The Netherlands). cDNA was amplified using specific primers (all from Integrated DNA Technologies, Inc. (IDT), Leuven, Belgium, see Table S3). Relative levels of gene expression were normalized to the $B 2 M$ housekeeping gene. The relative quantity of mRNA was calculated using the formula $2^{-\Delta C t} \times 1000$.

\subsection{Statistical Analysis}

Statistical analysis was performed using GraphPad Prism 8 (GraphPad Software, Inc., San Diego, CA, USA). Potential differences between experimental groups were analyzed by a parametric ANOVA test. $p<0.05$ was considered statistically significant.

\section{Conclusions}

The Sema4A-PlexinD1 axis is an important regulator of $\mathrm{T}$ helper cell differentiation and therefore regulating Sema4A levels might be a potential therapeutic approach in $\mathrm{CD}_{4}^{+} \mathrm{T}$ cell-mediated diseases. 
Supplementary Materials: Supplementary materials can be found at http://www.mdpi.com/1422-0067/21/18/ 6965/s1.

Author Contributions: Conceptualization, T.C., A.P.L., T.R.D.J.R. and S.G.; methodology, T.C., B.M.-F., A.P.L. and S.G.; formal analysis T.C., C.R.-V., B.M.-F., A.P.L., J.M.P-R., T.R.D.J.R. and S.G.; Writing-Original draft preparation, C.R.-V., and S.G.; Writing-Review and editing, T.C., C.R.-V., B.M.-F., A.P.L., J.M.P.-R., T.R.D.J.R. and S.G.; funding acquisition, T.R.D.J.R. and S.G. All authors have read and agreed to the published version of the manuscript.

Funding: This work was supported by the Dutch Arthritis Association (project grant NR18-1-301 to S. García). C.R-V. is supported by a predoctoral fellowship from Xunta de Galicia (IN606A-2020/043). T.C. and A.P.L. were supported by grants from the Portuguese National Funding Agency for Science, Research and Technology: Fundação para a Ciência e a Tecnologia (SFRH/BD/93526/2013 and SFRH/BD/116082/2016, respectively). S.G. is supported by the Miguel Servet program (CP19/00005) from the Instituto de Salud Carlos III (ISCIII) and the European Social Fund ("Investing in your future").

Acknowledgments: The authors would like to thank Michel Olde Nordkamp for technical support. The graphical abstract figure was created with BioRender.com.

Conflicts of Interest: The authors declare no conflict of interest.

$\begin{array}{ll}\text { Abbreviations } & \\ \text { Sema4A } & \text { Semaphorin4A } \\ \text { Th } & \text { T helper } \\ \text { IFN- } \gamma & \text { Interferon- } \gamma \\ \text { IL } & \text { Interleukin } \\ \text { ILT4 } & \text { Immunoglobulin-like transcript 4 } \\ \text { SSc } & \text { Systemic sclerosis } \\ \text { NRP-1 } & \text { Neuropilin-1 }\end{array}$

\section{References}

1. Zhu, J. T helper cell differentiation, heterogeneity, and plasticity. Cold Spring Harb. Perspect. Biol. 2018, 10, 1-18. [CrossRef] [PubMed]

2. Zhu, J.; Yamane, H.; Paul, W.E. Differentiation of Effector CD4 T Cell Populations. Annu. Rev. Immunol. 2010, 28, 445-489. [CrossRef]

3. Fang, D.; Zhu, J. Dynamic balance between master transcription factors determines the fates and functions of CD4 T cell and innate lymphoid cell subsets. J. Exp. Med. 2017, 214, 1861-1876. [CrossRef]

4. Szabo, S.J.; Sullivan, B.M.; Peng, S.L.; Glimcher, L.H. M Olecular M Echanisms R Egulating T H 1 I Mmune R Esponses. Annu. Rev. Immunol. 2003, 21, 713-758. [CrossRef] [PubMed]

5. Gaffen, S.L.; Jain, R.; Garg, A.V.; Cua, D.J. The IL-23-IL-17 immune axis: From mechanisms to therapeutic testing. Nat. Rev. Immunol. 2014, 14, 585-600. [CrossRef] [PubMed]

6. Korn, T.; Bettelli, E.; Oukka, M.; Kuchroo, V.K. IL-17 and Th17 Cells. Annu. Rev. Immunol. 2009, $27,485-517$. [CrossRef]

7. Murdaca, G.; Colombo, B.M.; Puppo, F. The role of Th17 lymphocytes in the autoimmune and chronic inflammatory diseases. Intern. Emerg. Med. 2011, 6, 487-495. [CrossRef]

8. Palm, N.W.; Rosenstein, R.K.; Medzhitov, R. Allergic host defences. Nature 2012, 484, 465-472. [CrossRef]

9. Licona-limón, P.; Kim, L.K.; Palm, N.W.; Flavell, R.A. REVIEW T H 2, allergy and group 2 innate lymphoid cells. Nat. Immunol. 2013, 14, 536-542. [CrossRef]

10. Worzfeld, T.; Offermanns, S. Semaphorins and plexins as therapeutic targets. Nat. Rev. Drug Discov. 2014, 13, 603-621. [CrossRef]

11. Nakatsuji, Y.; Okuno, T.; Moriya, M.; Sugimoto, T.; Kinoshita, M.; Takamatsu, H.; Nojima, S.; Kimura, T.; Kang, S.; Ito, D.; et al. Elevation of Sema4A Implicates Th Cell Skewing and the Efficacy of IFN- Therapy in Multiple Sclerosis. J. Immunol. 2012, 188, 4858-4865. [CrossRef] [PubMed]

12. Lu, N.; Li, Y.; Zhang, Z.; Xing, J.; Sun, Y.; Yao, S.; Chen, L. Human Semaphorin-4A drives Th2 responses by binding to receptor ILT-4. Nat. Commun. 2018, 9, 1-11. [CrossRef] [PubMed] 
13. Carvalheiro, T.; Affandi, A.J.; Malvar-Fernández, B.; Dullemond, I.; Cossu, M.; Ottria, A.; Mertens, J.S.; Giovannone, B.; Bonte-Mineur, F.; Kok, M.R.; et al. Induction of Inflammation and Fibrosis by Semaphorin 4A in Systemic Sclerosis. Arthritis Rheumatol. 2019, 71, 1711-1722. [CrossRef] [PubMed]

14. Kumanogoh, A.; Marukawa, S.; Suzuki, K.; Takegahara, N.; Watanabe, C.; Ch'ng, E.S.; Ishida, I.; Fujimura, H.; Sakoda, S.; Yoshida, K.; et al. Class iv semaphorin sema4a enhances t-cell activation and interacts with tim-2. Nature 2002, 419, 629-633. [CrossRef] [PubMed]

15. Toyofuku, T.; Yabuki, M.; Kamei, J.; Kamei, M.; Makino, N.; Kumanogoh, A.; Hori, M. Semaphorin-4A, an activator for T-cell-mediated immunity, suppresses angiogenesis via Plexin-D1. EMBO J. 2007, 26, 1373-1384. [CrossRef]

16. Delgoffe, G.M.; Woo, S.-R.; Turnis, M.E.; Gravano, D.M.; Guy, C.; Overacre, A.E.; Bettini, M.L.; Vogel, P.; Finkelstein, D.; Bonnevier, J.; et al. Stability and function of regulatory $\mathrm{T}$ cells is maintained by a neuropilin-1-semaphorin-4a axis. Nature 2013, 501, 252-256. [CrossRef]

17. Ito, D.; Nojima, S.; Nishide, M.; Okuno, T.; Takamatsu, H.; Kang, S.; Kimura, T.; Yoshida, Y.; Morimoto, K.; Maeda, Y.; et al. mTOR Complex Signaling through the SEMA4A-Plexin B2 Axis Is Required for Optimal Activation and Differentiation of CD8 ${ }^{+}$T Cells. J. Immunol. 2015, 195, 934-943. [CrossRef]

18. Chapoval, S.P.; Hritzo, M.; Qi, X.; Tamagnone, L.; Golding, A.; Keegan, A.D. Semaphorin 4A Stabilizes Human Regulatory T Cell Phenotype via Plexin B1. ImmunoHorizons 2019, 3, 71-87. [CrossRef]

19. Wang, L.; Song, G.; Zheng, Y.; Tan, W.; Pan, J.; Zhao, Y.; Chang, X. Expression of Semaphorin 4A and its potential role in rheumatoid arthritis. Arthritis Res. Ther. 2015, 17, 1-11. [CrossRef]

20. Kumanogoh, A.; Shikina, T.; Suzuki, K.; Uematsu, S.; Yukawa, K.; Kashiwamura, S.I.; Tsutsui, H.; Yamamoto, M.; Takamatsu, H.; Ko-Mitamura, E.P.; et al. Nonredundant roles of Sema4A in the immune system: Defective T cell priming and Th1/Th2 regulation in Sema4A-deficient mice. Immunity 2005, 22, 305-316. [CrossRef]

21. Nkyimbeng-Takwi, E.H.; Shanks, K.; Smith, E.; Iyer, A.; Lipsky, M.M.; Detolla, L.J.; Kikutani, H.; Keegan, A.D.; Chapoval, S.P. Neuroimmune semaphorin 4A downregulates the severity of allergic response. Mucosal Immunol. 2012, 5, 409-419. [CrossRef] [PubMed]

22. Morihana, T.; Goya, S.; Mizui, M.; Yasui, T.; Prasad, D.V.R.; Kumanogoh, A.; Tamura, M.; Shikina, T.; Maeda, Y.; Iwamoto, Y.; et al. An inhibitory role for Sema4A in antigen-specific allergic asthma. J. Clin. Immunol. 2013, 33, 200-209. [CrossRef] [PubMed]

23. Makino, N.; Toyofuku, T.; Takegahara, N.; Takamatsu, H.; Okuno, T.; Nakagawa, Y.; Kang, S.; Nojima, S.; Hori, M.; Kikutani, H.; et al. Involvement of Sema4A in the progression of experimental autoimmune myocarditis. FEBS Lett. 2008, 582, 3935-3940. [CrossRef] [PubMed]

24. Koda, T.; Okuno, T.; Takata, K.; Honorat, J.A.; Kinoshita, M.; Tada, S.; Moriya, M.; Sakoda, S.; Mochizuki, H.; Kumanogoh, A.; et al. Sema4A inhibits the therapeutic effect of IFN- $\beta$ in EAE. J. Neuroimmunol. 2014, 268, 43-49. [CrossRef]

25. Gasparini, G.; Cozzani, E.; Parodi, A. Interleukin-4 and interleukin-13 as possible therapeutic targets in systemic sclerosis. Cytokine 2020, 125, 154799. [CrossRef]

26. Allanore, Y.; Simms, R.; Distler, O.; Trojanowska, M.; Pope, J.; Denton, C.P.; Varga, J. Systemic sclerosis. Nat. Rev. Dis. Prim. 2015, 1, 1-21. [CrossRef]

27. Radstake, T.R.D.J.; van Bon, L.; Broen, J.; Hussiani, A.; Hesselstrand, R.; Wuttge, D.M.; Deng, Y.; Simms, R.; Lubberts, E.; Lafyatis, R. The pronounced Th17 profile in systemic sclerosis (SSc) together with intracellular expression of TGF?? and IFN?? distinguishes SSc phenotypes. PLoS ONE 2009, 4, e5903. [CrossRef]

28. Truchetet, M.E.; Brembilla, N.C.; Montanari, E.; Lonati, P.; Raschi, E.; Zeni, S.; Fontao, L.; Meroni, P.L.; Chizzolini, C. Interleukin-17A+ Cell Counts Are Increased in Systemic Sclerosis Skin and Their Number Is Inversely Correlated with the Extent of Skin Involvement. Arthritis Rheum. 2013, 65, 1347-1356. [CrossRef]

29. Gonçalves, R.S.G.; Pereira, M.C.; Dantas, A.T.; de Almeida, A.R.; Marques, C.D.L.; Rego, M.J.B.M.; Pitta, I.R.; Duarte, A.L.B.P.; Pitta, M.G.R. IL-17 and related cytokines involved in systemic sclerosis: Perspectives. Autoimmunity 2018, 51, 1-9. [CrossRef]

30. Kumanogoh, A.; Kikutani, H. Immunological functions of the neuropilins and plexins as receptors for semaphorins. Nat. Rev. Immunol. 2013, 13, 802-814. [CrossRef]

31. Suzuki, K.; Kumanogoh, A.; Kikutani, H. Semaphorins and their receptors in immune cell interactions. Nat. Immunol. 2008, 9, 17-23. [CrossRef] [PubMed] 
32. Yang, W.; Hu, J.; Uemura, A.; Tetzlaff, F.; Augustin, H.G.; Fischer, A. Semaphorin-3C signals through Neuropilin-1 and PlexinD1 receptors to inhibit pathological angiogenesis. EMBO Mol. Med. 2015, 7, 1267-1284. [CrossRef]

33. Liu, X.; Uemura, A.; Fukushima, Y.; Yoshida, Y.; Hirashima, M. Semaphorin 3G Provides a Repulsive Guidance Cue to Lymphatic Endothelial Cells via Neuropilin-2/PlexinD1. Cell Rep. 2016, 17, 2299-2311. [CrossRef] [PubMed]

34. Hamm, M.J.; Kirchmaier, B.C.; Herzog, W. Sema3d controls collective endothelial cell migration by distinct mechanisms via nrp1 and plxnD1. J. Cell Biol. 2016, 215, 415-430. [CrossRef] [PubMed]

35. Zhang, Y.; Singh, M.K.; Degenhardt, K.R.; Lu, M.M.; Bennett, J.; Yoshida, Y.; Epstein, J.A. Tie2Cre-mediated inactivation of plexinD1 results in congenital heart, vascular and skeletal defects. Dev. Biol. 2009, 325, 82-93. [CrossRef] [PubMed]

36. Bribián, A.; Nocentini, S.; Llorens, F.; Gil, V.; Mire, E.; Reginensi, D.; Yoshida, Y.; Mann, F.; Del Río, J.A. Sema3E/PlexinD1 regulates the migration of hem-derived Cajal-Retzius cells in developing cerebral cortex. Nat. Commun. 2014, 5, 1-14. [CrossRef]

37. Gu, C.; Yoshida, Y.; Livet, J.; Reimert, D.V.; Mann, F.; Merte, J.; Henderson, C.E.; Jessell, T.M.; Kolodkin, A.L.; Ginty, D.D. Semaphorin 3E and plexin-D1 control vascular pattern independently of neuropilins. Science 2005, 307, 265-268. [CrossRef]

38. Mata, A.; Gil, V.; Pérez-Clausell, J.; Dasilva, M.; González-Calixto, M.C.; Soriano, E.; García-Verdugo, J.M.; Sanchez-Vives, M.V.; Del Río, J.A. New functions of Semaphorin 3E and its receptor PlexinD1 during developing and adult hippocampal formation. Sci. Rep. 2018, 8, 1-16. [CrossRef]

39. Sawada, M.; Ohno, N.; Kawaguchi, M.; Huang, S.-H.; Hikita, T.; Sakurai, Y.; Bang Nguyen, H.; Quynh Thai, T.; Ishido, Y.; Yoshida, Y.; et al. PlexinD1 signaling controls morphological changes and migration termination in newborn neurons. EMBO J. 2018, 37, e97404. [CrossRef]

40. Sandireddy, R.; Cibi, D.M.; Gupta, P.; Singh, A.; Tee, N.; Uemura, A.; Epstein, J.A.; Singh, M.K. Semaphorin 3E/PlexinD1 signaling is required for cardiac ventricular compaction. JCI Insight 2019, 4, e125908. [CrossRef]

41. Van Den Hoogen, F.; Khanna, D.; Fransen, J.; Johnson, S.R.; Baron, M.; Tyndall, A.; Matucci-Cerinic, M.; Naden, R.P.; Medsger, T.A.; Carreira, P.E.; et al. 2013 classification criteria for systemic sclerosis: An american college of rheumatology/European league against rheumatism collaborative initiative. Arthritis Rheum. 2013, 65, 2737-2747. [CrossRef] [PubMed] 